\title{
The Influence of Air and Subsequent Vacuum Thermal Treatment on the Thermoelectric Properties of Extruded $\mathrm{TiO}_{2}$ Ceramics
}

\author{
Kristaps Rubenis ${ }^{1}$, Valdis Teteris ${ }^{2}$, Janis Locs ${ }^{3}$, Janis Barloti ${ }^{4}$, Liga Berziṇa - Cimdina ${ }^{5}$, \\ ${ }^{1-5}$ Riga Technical University
}

\begin{abstract}
The thermoelectric properties of air sintered and vacuum annealed $\mathrm{TiO}_{2}$ samples consolidated by the extrusion process have been studied. The samples were sintered in air at $1100,1175,1250$ and $1350{ }^{\circ} \mathrm{C}$ and subsequently annealed under vacuum at $1075{ }^{\circ} \mathrm{C}$. After both thermal treatments oxygen deficient phases were not observed and only a single rutile $\mathrm{TiO}_{2}$ phase was present in the samples. The density and grain size of the samples increased with an increase in air sintering temperature, while the total porosity decreased. Electrical conductivity of the samples increased with an increase in air sintering temperature. The highest Seebeck coefficient $(\sim 410$ $\mu \mathrm{V} / \mathrm{K})$ and thermoelectric power factor $\left(3,25 \times 10^{-6} \mathrm{~W} / \mathrm{m}^{-1} \mathrm{~K}^{-2}\right)$ at $280{ }^{\circ} \mathrm{C}$ were obtained for the sample that was sintered in air at $1175^{\circ} \mathrm{C}$ before the following annealing under vacuum.
\end{abstract}

Keywords: $\mathrm{TiO}_{2}$, ceramics, microstructure, thermoelectric properties

\section{INTRODUCTION}

Approximately $90 \%$ of the world's power is generated by heat engines. Most heat engines use fossil fuel to provide heat, which is then converted to work. In the energy conversion process, a large fraction of the energy content is lost as waste heat (typical heat engines operate at 30-40 per cent efficiency, which means that more than half of the fuel energy is expelled as waste heat) [1].

One way to recover part of this waste heat is to use thermoelectric materials that can directly and reversibly convert heat to electrical energy. This process is based on the Seebeck effect, which describes the voltage induced by the temperature difference across a material. The voltage produced is proportional to the temperature difference across the material. The proportionality constant is defined as the Seebeck coefficient and is obtained from the ratio of the voltage generated and the applied temperature difference: $S=\Delta V / \Delta T$ [2]. The performance of thermoelectric material is driven by its figure of merit $Z T$, a parameter determining the efficiency of thermoelectric conversation and is defined as $Z T=S^{2} \sigma T / k$, where $S, \sigma, T$ and $k$ are the Seebeck coefficient, electrical conductivity, temperature and thermal conductivity, respectively [3]. The product $\left(S^{2} \sigma\right)$ is called the power factor. It is commonly used to evaluate the performance of thermoelectric materials [2].

The challenge of research on the thermoelectric materials $r$ is to increase values for $Z T$. Figure of merit of the material can be increased by increasing the power factor $S^{2} \sigma$ and/or decreasing the thermal conductivity $k$. These parameters in $Z T$ vary with carrier concentration. Therefore, controlling carrier concentration is an essential prerequisite for optimizing the $Z T$ values $[4,5]$.

The most widely used commercial thermoelectric material is bulk $\mathrm{Bi}_{2} \mathrm{Te}_{3}$ and its alloys [6,7]. Since tellurium is extremely rare found in the Earth's crust [8], it would be desirable to develop alternative materials that minimize the use of rare elements and involve cheaper and widely available elements.

Transition metal oxides have been attracting increasing attention owing to their good thermoelectric properties, innocuity and low costs [9]. Among the transitional metal oxides, $\mathrm{TiO}_{2}$ might be considered one of the most promising thermoelectric materials $[10,11]$.

$\mathrm{TiO}_{2}$ is a dielectric material with the band gap width $\sim 3 \mathrm{eV}$ and is used in a wide range of applications because of its nontoxicity, thermal stability, high oxidation resistance and controllable semiconducting properties [9]. $\mathrm{TiO}_{2}$ occurs in three distinct polymorphs: rutile, anatase, and brookite, but only rutile and anatase are of technical importance.

For thermoelectric applications, the electrical conductivity of $\mathrm{TiO}_{2}$ should be increased. It can be achieved by reduction treatment and impurity doping. If $\mathrm{TiO}_{2}$ is thermally treated in a reducing atmosphere (gaseous, vacuum), various defects, such as oxygen vacancies and $\mathrm{Ti}^{3+}$ defects, are formed in its crystal lattice and non-stochiometric compounds are formed, which can be described with a general formula $\mathrm{Ti}_{\mathrm{n}} \mathrm{O}_{2 \mathrm{n}-1}$ or $\mathrm{TiO}_{2-n}[12]$.

In stoichiometric $\mathrm{TiO}_{2}$ crystal, the metal atom is in $3 \mathrm{~d}^{0}$ $\left(\mathrm{Ti}^{4+}\right)$ electronic configuration. During reduction, $\mathrm{Ti}^{4+}$ ions can receive electrons from reducing gases or lattice oxygen usually removed from stoichiometric $\mathrm{TiO}_{2}$. As a result, $\mathrm{Ti}_{2} \mathrm{O}_{3}$ regions in $\mathrm{TiO}_{2}$ lattice can be formed, in which the metal atom is in $3 \mathrm{~d}^{1}\left(\mathrm{Ti}^{3+}\right)$ configuration [13]. Due to such lattice defects, local energy levels inside the band gap of $\mathrm{TiO}_{2}$ can be formed, and electrical conductivity of the oxide significantly increases [14]. Even slight deviations from stoichiometric $\mathrm{TiO}_{2}$ can significantly increase its electrical conductivity [15]. If there is a large oxygen deficit in the $\mathrm{TiO}_{2}$ structure, share of crystallographic planes occurs in the crystal lattice and the socalled Magneli phases are formed [16]. Magneli phases are a range of non-stoichiometric titanium oxides with the general formula $\mathrm{Ti}_{\mathrm{n}} \mathrm{O}_{2 \mathrm{n}-1}$, where $\mathrm{n}$ is between 4 and 10. These oxides can be obtained by reducing titanium dioxide at high temperatures in $\mathrm{H}_{2}$ atmosphere. As a result, ceramic materials with high electrical conductivity similar to that of graphite are obtained. Magneli phase titanium oxides show relatively high thermoelectric performance $[10,17]$. 
It is also known that electrical properties of ceramics containing titanium oxides can be affected by various microstructural defects (pores, grain boundaries, etc.) [18, 19].

In the present study, we investigate the influence of air and subsequent vacuum thermal treatment on the microstructure and thermoelectric properties of $\mathrm{TiO}_{2}$ ceramics formed by extrusion, which is a cost-effective method to produce objects with a cross-sectional profile.

\section{MATERIALS AND METHODS}

To produce a paste for extrusion, commercial $\mathrm{TiO}_{2}$ powder (Sachtleben Chemie GmbH, Hombitan $L W-S$ ) with purity greater than $99 \%$ and average particle size of $300 \mathrm{~nm}$ was mixed with $18 \mathrm{wt} \%$ water and $2 \mathrm{wt} \%$ additives (plasticizer, lubricant) in a kneader-mixer $(A M K, I I I U$ $8 / I V)$ at constant temperature of $20{ }^{\circ} \mathrm{C}$ and a rotor speed of $30 \mathrm{rpm}$. The paste was then transferred to a vacuum extrusion press (Dorst, V10 $\mathrm{SpHv}$ ) and formed to cylindrical green bodies with a diameter of $13 \mathrm{~mm}$ and length of about $100 \mathrm{~mm}$. The consolidated green bodies were first dried at room temperature for 3 days in order to remove residual water and prevent crack formation. After drying the green body compacts were pressureless sintered in air at $1100,1175,1250$ and $1350{ }^{\circ} \mathrm{C}$ for $5 \mathrm{~h}$ with a heating and cooling rate of $3{ }^{\circ} \mathrm{C} / \mathrm{min}$. In order to increase free carrier concentration, after sintering the samples were annealed under vacuum $\left(2 \times 10^{-5}\right.$ mbar $)$ at $1075^{\circ} \mathrm{C}$ for $3 \mathrm{~h}$ with heating and cooling rate of $5^{\circ} \mathrm{C} / \mathrm{min}$.

Density, open and closed porosity of the sintered and vacuum annealed samples were determined using a method based on Archimedes' principle [20]. The density values obtained from measurements were related to the theoretical density of anatase or rutile $\mathrm{TiO}_{2}$.

Crystal phases of thermally treated samples were revealed by X-ray powder diffraction using PANalitical X'pert PRO model X-ray diffractometer (XRD) with $\mathrm{Cu} \mathrm{K} \mathrm{K}_{\alpha}$ radiation. For microstructural characterization, the samples after thermal treatment were fractured and then studied using the scanning electronic microscope (SEM) Tescan Mira/LMU.

In order to measure thermoelectric properties of the samples, after thermal treatment they were cut in $20 \mathrm{~mm}$ long cylinders. The Seebeck coefficient and the electrical resistivity of the samples were measured under a vacuum in the temperature range from room temperature to $300{ }^{\circ} \mathrm{C}$ in a selfmade apparatus. To ensure good electrical contact between the samples and the measurement device, copper was deposited on both ends of the samples in a thermal vacuum evaporator.

\section{RESULTS AND DISCUSSION}

Fig. 1. shows XRD patterns of the air sintered (1100, 1250 and $1350{ }^{\circ} \mathrm{C}$ ) and vacuum annealed samples. During a thermal treatment phase, transition from anatase to rutile occurred and only a single rutile $\mathrm{TiO}_{2}$ phase was present in all of the samples. Oxygen deficient $\mathrm{TiO}_{2-n}$ phases after vacuum annealing were not observed.

Density and porosity of the samples as a function of air sintering temperature are shown in Fig. 2 and Fig. 3. As seen in Fig. 2, the density of the samples increases with an increase in the sintering temperature and reaches approximately $83 \%$ of the theoretical density at $1350{ }^{\circ} \mathrm{C}$. The open porosity of the samples (Fig. 3) decreases with an increase in heat treatment temperatures, while closed porosity remains essentially the same for all sintering temperatures. Since vacuum annealing temperature $\left(1075^{\circ} \mathrm{C}\right)$ is lower than air sintering temperature, it does not affect the density and porosity of the samples.

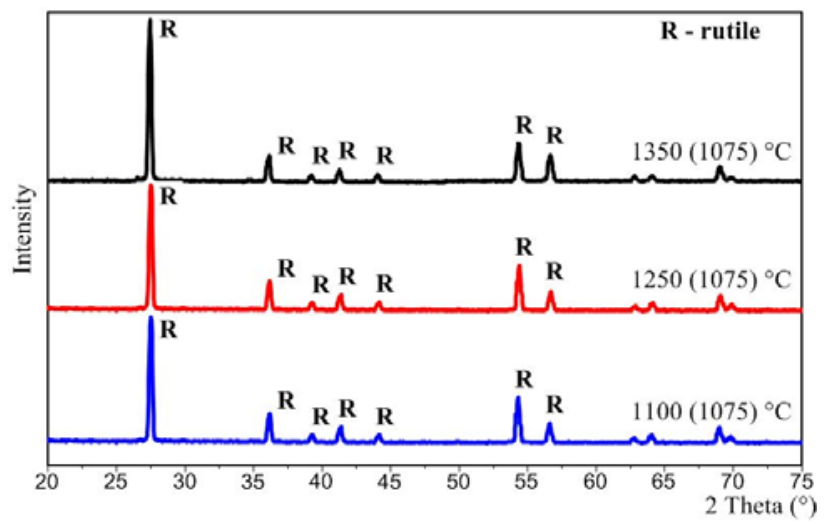

Fig. 1. XRD patterns of the samples after thermal treatment
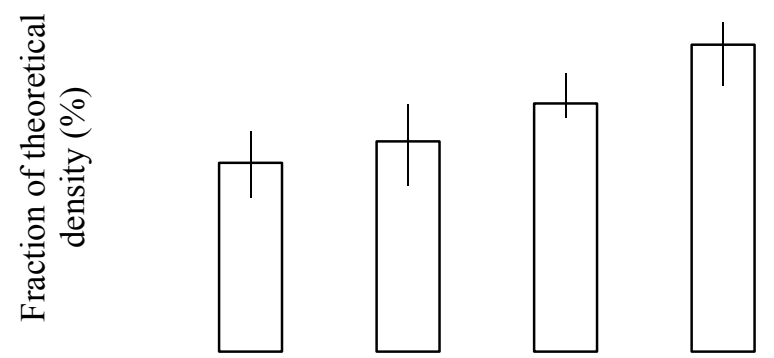

Sintering temperature $\left({ }^{\circ} \mathrm{C}\right)$

Fig. 2. Density of the samples as a function of sintering temperature

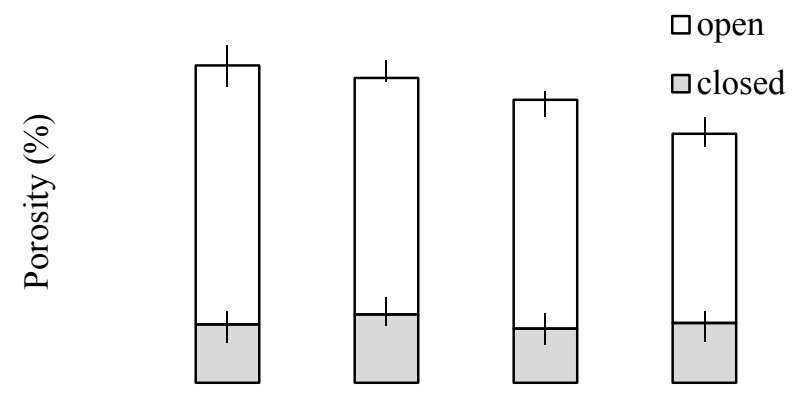

Sintering temperature $\left({ }^{\circ} \mathrm{C}\right)$

Fig. 3. Porosity of the samples as a function of sintering temperature

SEM micrographs of fracture surfaces of the samples after sintering in air at 1100,1250 and $1350{ }^{\circ} \mathrm{C}$ and subsequent vacuum annealing at $1075^{\circ} \mathrm{C}$ are shown in Fig. 4 . As seen, the grain size of the samples increases with an increase in the sintering temperature. For the samples sintered at $1100{ }^{\circ} \mathrm{C}$, the grains are mostly elongated in shape. For sintering temperatures from $1250{ }^{\circ} \mathrm{C}$, the grains become more equiaxed. 


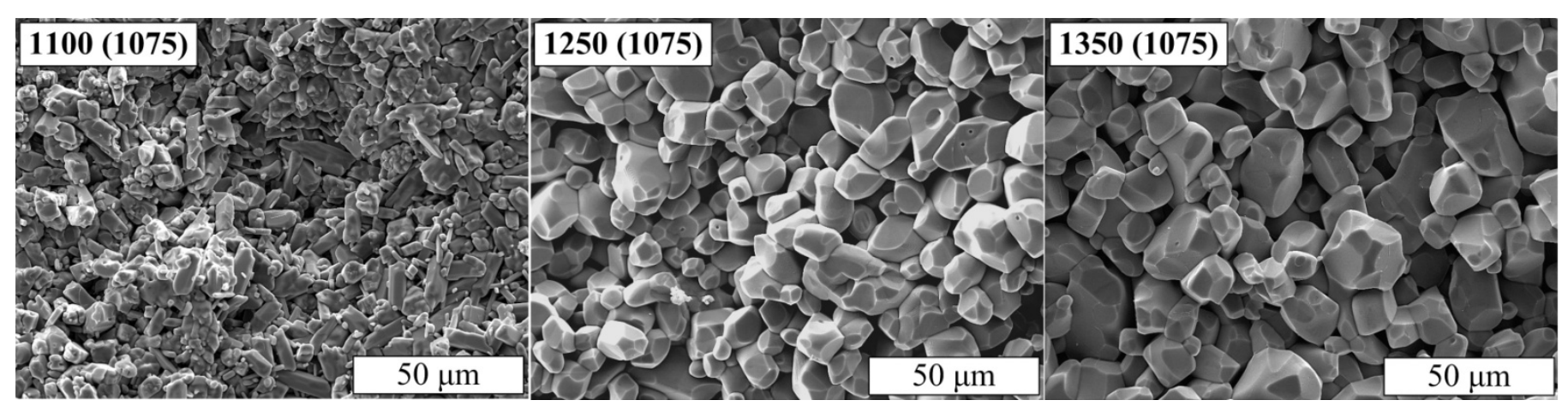

Fig. 4. SEM micrographs of fracture surfaces of the air sintered and vacuum annealed samples

The temperature dependence of the electrical conductivity of the air sintered and vacuum annealed samples are demonstrated in Fig. 5. The behaviour of electrical conductivity for the samples is semiconducting as their conductivity increases with increasing temperature. As can be seen, conductivity of the samples is related to their microstructures formed during air sintering. Electrical conductivity increases as the grain size of the samples increases and porosity decreases. This effect can be caused by the grain boundary area, which is much smaller with coarse grains. In the samples with a reduced grain boundary area there is less electrical barrier present. Also effective conducting volume is smaller for the samples with higher porosity, which can be another reason for the differences in conductivities of the samples [18].

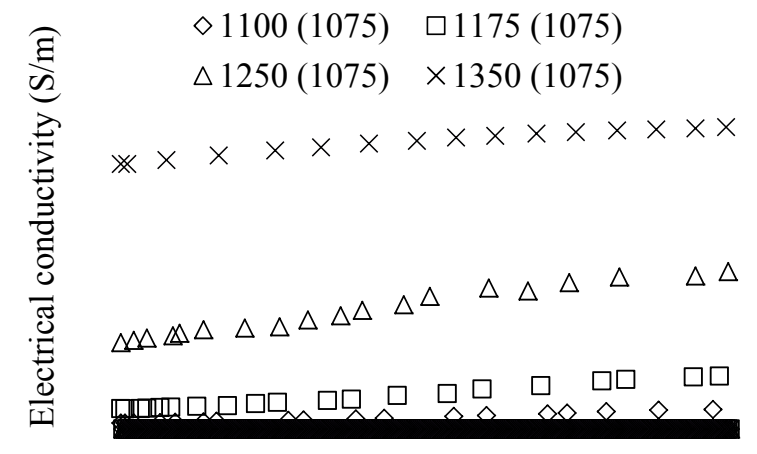

Measurement temperature $\left({ }^{\circ} \mathrm{C}\right)$

Fig. 5. The electrical conductivity of the air sintered and vacuum annealed samples as a function of temperature

Fig. 6 shows the temperature dependence of the Seebeck coefficient for the samples. Increase in electrical conductivity (Fig. 5) for most of the samples decreases their Seebeck coefficient. It is well known that the absolute values of Seebeck coefficient decrease with an increase in carrier concentration. However, the highest Seebeck coefficient values are shown by the sample sintered in air at $1175{ }^{\circ} \mathrm{C}$, with maximum value $(\sim 410 \mu \mathrm{V} / \mathrm{K})$ around $280{ }^{\circ} \mathrm{C}$, while its electrical conductivity is higher than that of the sample sintered at $1100{ }^{\circ} \mathrm{C}$. It is possible that the samples sintered at $1175^{\circ} \mathrm{C}$ have lower carrier concentration but higher carrier mobility than the samples sintered at $1100{ }^{\circ} \mathrm{C}$. For the samples sintered at 1100 and $1175{ }^{\circ} \mathrm{C}$, the Seebeck coefficient increases with increasing temperature, while for the samples sintered at 1250 and $1350{ }^{\circ} \mathrm{C}$ it decreases or remains the same.

Values of thermoelectric power factor $\left(S^{2} \sigma\right)$ for the samples as a function of temperature can be seen in Fig. 7. Power factor is mainly influenced by the electrical conductivity of the samples. It increases monotonically with temperature. The highest value of thermoelectric power factor is obtained at 300 ${ }^{\circ} \mathrm{C}\left(3.25 \times 10^{-6} \mathrm{~W} / \mathrm{m}^{-1} \mathrm{~K}^{-2}\right)$ for the samples sintered at $1175^{\circ} \mathrm{C}$.

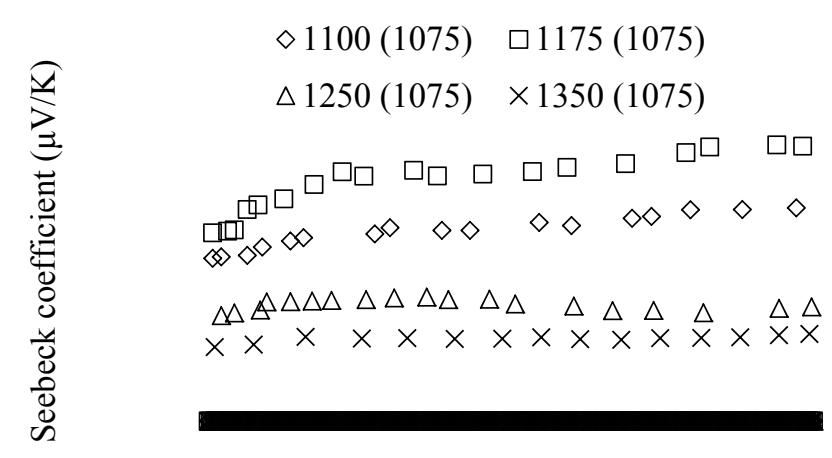

Measurement temperature $\left({ }^{\circ} \mathrm{C}\right)$

Fig. 6. The Seebeck coefficient of the air sintered and vacuum annealed samples as a function of temperature

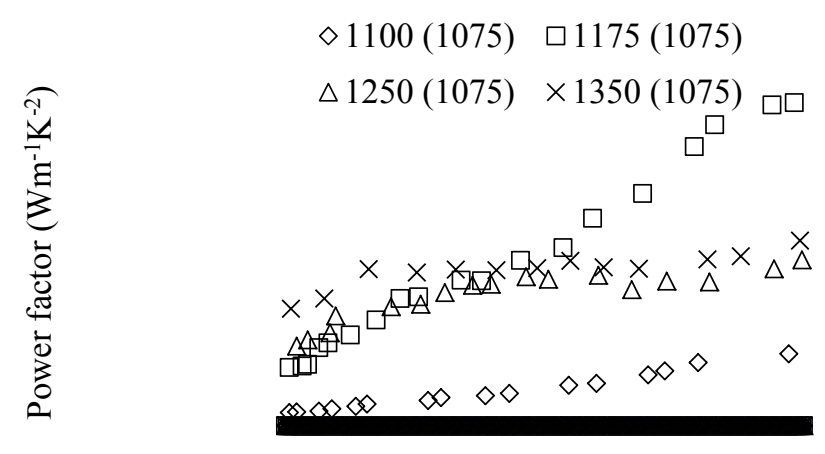

Measurement temperature $\left({ }^{\circ} \mathrm{C}\right)$

Fig. 7. The power factor of the air sintered and vacuum annealed samples as a function of temperature 


\section{CONCLUSIONS}

The thermoelectric properties of air sintered and vacuum annealed $\mathrm{TiO}_{2}$ samples formed by the extrusion method have been investigated. The samples were sintered in air at 1100 , 1175,1250 and $1350{ }^{\circ} \mathrm{C}$ and subsequently annealed under vacuum at $1075^{\circ} \mathrm{C}$. The electrical conductivity of the samples increases with an increase in air sintering temperature. The highest Seebeck coefficient $(\sim 410 \mu \mathrm{V} / \mathrm{K})$ and thermoelectric power factor $\left(3.25 \times 10^{-6} \mathrm{~W} / \mathrm{m}^{-1} \mathrm{~K}^{-2}\right)$ at $280{ }^{\circ} \mathrm{C}$ were obtained for the samples sintered at $1175^{\circ} \mathrm{C}$.

\section{ACKNOWLEDGEMENTS}

The research has been supported by the European Regional Development Fund within the framework of the project "Development of Innovative Water Processing Technology Using Nanostructured Ceramics", No. 2010/0257/2DP/2.1.1.1.0/10/APIA/VIAA/012.

\section{REFERENCES}

1. Hochbaum, A.I., Chen, R., Delgado, R.D., Liang, W., Garnett, E.C Najarian, M., Majumdar, A., Yang, P. Enhanced thermoelectric performance of rough silicon nanowires. Nature, 2008, vol. 451, p. 163 167. http://dx.doi.org/10.1038/nature06381

2. Goldsmith, J.G. Introduction to Thermoelectricity. Springer, Berlin, 2009, p. $1-44$. http://dx.doi.org/10.1007/978-3-642-00716-3 http://dx.doi.org/10.1007/978-3-642-00716-3 1

3. Wu, L., Zheng, J-C., Zhou, J., Li, Q., Yang, J., Zhu, Y. Nanostructures and defects in thermoelectric $\mathrm{AgPb}_{18} \mathrm{SbTe}_{20}$ single crystal. Journal of Applied Physics, 2009, vol. 105, 094317. http://dx.doi.org/10.1063/1.3124364

4. Kauzlaich, S.M., Brown, S.R., Snyder, G.J. Zintl phases for thermoelectric devices. Dalton Transactions, 2007, vol. 21, p. 2099 2107. http://dx.doi.org/10.1039/b702266b

5. Han, M-K., Zhou, X., Uher, C., Kim, S-J., Kantzidis, M.G. Increase in the Figure of Merit by Cd-Substitution in $\mathrm{Sn}_{1-\mathrm{x}} \mathrm{Pb}_{\mathrm{x}} \mathrm{Te}$ and Effect of $\mathrm{Pb} / \mathrm{Sn}$ Ratio on Thermoelectric Properties. Advanced Energy Materials, 2012, vol. 2, p. 1218 - 1225. http://dx.doi.org/10.1002/aenm.201200083

6. Bisawa, K., Zhao, L-D., Kanatzidis, M.G. Tellurium-Free Thermoelectric: The Anisotropic n-Type Semiconductor $\mathrm{Bi}_{2} \mathrm{~S}_{3}$. Advanced Energy Materials, 2012, vol. 2, p. $634 \quad$ - 638 http://dx.doi.org/10.1002/aenm.201100775

7. Ma, Y., Ahlberg, E., Sun, Y., Iversen, B.B., Palmquist, A.E.C Thermoelectric properties of thin films of bismuth telluride electrochemically deposited on stainless steel substrates. Electrochimica Acta, 2011, vol. 56, p. $4216 \quad-\quad 4223$ http://dx.doi.org/10.1016/j.electacta.2011.01.093

8. Hu, Z., Gao, S. Upper crustal abundances of trace elements: A revision and update. Chemical Geology, 2008, vol. 253, p. 205 - 221 http://dx.doi.org/10.1016/j.chemgeo.2008.05.010

9. Liu, C., Miao, L., Zhou, J., Huang, R., Tanemura, S. Bottom-up assembly to $\mathrm{Ag}$ nanoparticles embedded $\mathrm{Nb}$-dopped $\mathrm{TiO}_{2}$ nanobulks with improved n-type thermoelectric properties. Journal of Materials Chemistry, 2012, vol. 22, p. $14180 \quad$ - 14190 http://dx.doi.org/10.1039/c2jm31469j

10.Harada, S., Tanaka, K., Inui, H. Thermoelectric properties and crystallographic shear structures in titanium oxides of the Magneli phases. Journal of applied physics, 2010, vol. 108, p. 083703. http://dx.doi.org/10.1063/1.3498801

11.Lu, Y., Sagara, K., Hao, L., Ji, Z., Yoshida, H. Fabrication of NonStoichiometric Titanium Dioxide by Spark Plasma Sintering and Its Thermoelectric Properties. Materials Transactions, 2012, vol. 53, N. 7, p. 1208 - 1211. http://dx.doi.org/10.2320/matertrans.E-M2012808
12.Diebold, U. The surface science of titanium dioxide. Surface Science reports, 2003, vol. 48, p. 53 - 229. http://dx.doi.org/10.1016/S01675729(02)00100-0

13.Klusek, Z., Pierzgalski, S., Datta, S. Insulator-metal transition on heavily reduced $\mathrm{TiO}_{2}(110)$ surface studied by high temperature scanning tunneling spectroscopy (HT-STS). Applied Surface Science, 2004, vol. 221, p. $120-$ 128. http://dx.doi.org/10.1016/S0169-4332(03)00877-8

14.Hossain, F.M., Murch, G.E. The Effect of Defect Disorder on the Electronic Structure of Rutile $\mathrm{TiO}_{2-\mathrm{x}}$. Deffect and Diffusion Forum, 2006 , vol. $251-252$, p. $1-12$

15.Jak, M.J.J., Kreuningen, A., Verhoeven, J., Frenken, J.W.M. The effect of stoichiometry on the stability of steps on $\mathrm{TiO}_{2}$ (110). 2002, Applied Surface Science, vol. 201, p. 161 - 170. http://dx.doi.org/10.1016/S0169-4332(02)00844-9

16.Smith, J.R., Walsh, F.C. Electrodes based on Magneli phase titanium oxides: the properties and Applications of Ebonex materials. Journal of Applied Electrochemistry, 1998, vol. 28, p. 1021 - 1033. http://dx.doi.org/10.1023/A:1003469427858

17.Lu, Y., Matsuda, Y., Sagara, K., Hao, L., Otomitsu, T., Yoshida, H. Fabrication and Thermoelectric Properties of Magneli Phases by Adding Ti into $\mathrm{TiO}_{2}$.

18.Song, S.H., Wang, X., Xiao, P. Effect of microstructural features on the electrical properties of $\mathrm{TiO}_{2}$. Materials Science and Engineering, 2002, vol. B94, p. 40 - 47. http://dx.doi.org/10.1016/S0921-5107(02)00072-7

19.Demetry, C., Shi, X. Grain size dependent electrical properties of rutile $\left(\mathrm{TiO}_{2}\right)$. Solid State Ionics, 1999, vol. 118, p. 271 - 279. http://dx.doi.org/10.1016/S0167-2738(98)00454-8

20.Kwan, Y.B.P., Alcock, J.R. The impact of water impregnation method on the accuracy of open porosity measurements. Journal of Materials Science, 2002, vol. 37, p. 2557 - 2561. http://dx.doi.org/10.1023/A:1015460127828

Kristaps Rubenis, Mg.sc.ing., Researcher at the Department of General Chemical Engineering, Riga Technical University. Research interests are related to $\mathrm{TiO}_{2}$ and nonstoichiometric titanium oxides containing ceramics.

E-mail: kristaps.rubenis@rtu.lv

Valdis Teteris, Researcher at the Division of Electronic Equipment, Riga Technical University. His research interests are related to electrical properties of various materials.

Janis Locs, Dr.sc.ing, Technical Director of Riga Biomaterials Innovation and Development Centre of RTU. He is the author and co-author of more than 25 publications in the field of hydroxiapatite, $\mathrm{SiC}$ and $\mathrm{TiO}_{2}$ ceramics.

E-mail: janis.locs@,rtu.lv

Janis Barloti. He received his Master's Degree in Physics from the University of Latvia (1963). He continued his post-graduate studies at the Division of Electronic Equipment and Technology at St. Petersburg State Electrotechnical University. Currently he is an Assistant Professor at the Division of Electronic Equipment, Riga Technical University. His research interests are related to the production of two-dimensional materials using vapour deposition and sputtering, as well investigation of the electrical properties of transition metal oxide ceramics.

Liga Berzina-Cimdina, Dr.sc.ing, a Professor, the Head of the Institute of General Chemical Engineering and Director of Riga Biomaterials Innovation and Development Centre. She is the Head of the Department of General Chemical Engineering at RTU, the Faculty of Materials Science and Applied Chemistry. She manages study programme specializations for: Chemistry and Technology of Biomaterials, Environmental Engineering, General Chemical Technology. Scientific research activities of Prof. L.Berzina-Cimdina include the management of international and regional projects (the EU, the Balkan countries, Latvia), development of new biomaterials and eco-materials, research of new applications for these materials and research on the interaction of materials and biological systems. She is the author of more than 100 scientific publications, as well as the author and a co-author of 3 patents. E-mail: liga.berzina-cimdina@rtu.lv

Kristaps Rubenis, Valdis Teteris, Jānis Locs, Jānis Barloti, Līga Bērziṇa-Cimdiṇa. Ekstrudētas TiO ${ }_{2}$ keramikas termoelektriskās īpašības pēc termiskās apstrādes gaisa vidē un sekojošas termiskās apstrādes vakuuma apstākḷos

Darbā pētīta termiskās apstrādes (gaisa un vakuuma apstākḷos) ietekme uz ekstrūzijas ceḷā iegūtas $\mathrm{TiO}_{2}$ keramikas termoelektriskajām īpašībām. No komerciāla $\mathrm{TiO}_{2}$ pulvera, ūdens un piedevām izgatavota plastiska masa. No iegūtās masas ar ekstrūzijas paņēmienu formēti apaļa šķērsgriezuma stienīši (paraugi). Pēc žāvēšanas tie saķepināti gaisa vidē $1100,1175,1250$ vai $1350{ }^{\circ} \mathrm{C}$ temperatūrā. Pēc saķepināšanas stienīši 
termiski apstrādāti vakuuma apstākḷıs $1075{ }^{\circ} \mathrm{C}$ temperatūrā, elektrovadītspējas uzlabošanai. Termiski apstrādātajiem paraugiem noteikts kristālisko fāžu sastāvs, blīvums un porainība, pētīta mikrostruktūra, mērīta elektrovadītspēja un Zēbeka koeficients temperatūru intervālā no 20 līdz $300{ }^{\circ} \mathrm{C}$, aprēḳināts termoelektriskais jaudas faktors. Pēc termiskās apstrādes visos paraugos novēroti tikai rutila kristāliskajai fāzei atbilstošie maksimumi, nestehiometriskie $\mathrm{TiO}_{2-n}$ savienojumi netika konstatēti. Palielinot paraugu termiskās apstrādes temperatūru gaisa vidē, pieaug paraugu blīvums un graudu izmērs, savukārt porainība samazinās. Konstatēts, ka paraugu elektriskās īpašības būtiski ietekmē mikrostruktūra, kāda tajos izveidojusies saķepināšanas laikā gaisa vidē. Pieaugot blīvumam un graudu izmēram (palielinoties saḳepināšanas temperatūrai gaisa vidē), paraugu elektrovadītspēja pieaug, lai gan vakuuma termiskā apstrāde visiem paraugiem veikta identiskā $\left(1075{ }^{\circ} \mathrm{C}\right)$ temperatūrā. Nosakot paraugu termoelektriskās īpašības, konstatēts, ka visu paraugu elektrovadītspēja pieaug, paaugstinoties to temperatūrai. Augstāko Zēbeka koeficientu $(\sim 410 \mu \mathrm{V} / \mathrm{K})$ un termoelektrisko jaudas faktoru $\left(3,25 \times 10^{-6} \mathrm{~W} / \mathrm{m}^{-1} \mathrm{~K}^{-2}\right) 280{ }^{\circ} \mathrm{C}$ temperatūrā uzrāda paraugi, kuri pirms termiskās apstrādes vakuuma apstākḷıs gaisa vidē saķepināti $1175^{\circ} \mathrm{C}$ temperatūrā.

Кристапс Рубенис, Валдис Тетерис, Янис Лочс, Янис Барлоти, Лига Берзиня-Цимдиня. Зависимость термоэлектрических свойств образцов из керамики $\mathrm{TiO}_{2}$, полученных путём экструзии, от термообработки в воздушной среде и последующей термообработки в условиях высокого вакуума.

Исследовано влияние термической обработки на воздухе и в условиях высокого вакуума на термоэлектрические свойства образцов керамики $\mathrm{TiO}_{2}$. Пластическая масса приготовлена из коммерческого порошка $\mathrm{TiO}_{2}$, воды и связывающих добавок. Из полученной массы путём экструзии изготовлены образцы круглого сечения. После сушки образцы спекались в воздушной среде при температурах $1100,1175,1250$ и $1350{ }^{\circ} \mathrm{C}$, потом подвергались термообработке в условиях высокого вакуума при температуре 1075 ${ }^{\circ} \mathrm{C}$. Для образцов определены: состав кристаллографических фаз, плотность, пористость, микроструктура, электропроводность и коэффициент Зеебека в интервале температур от 20 до $300^{\circ} \mathrm{C}$, а также термоэлектрический фактор мощности. Во всех образцах после термообработки констатирована кристаллическая фаза - рутил. Нестехиометрические соединения типа ТiО 2 -n не обнаружены. При увеличении температуры термообработки в воздушной среде увеличивается плотность и размер зерен, а пористость уменьшается. Обнаружено, что на электрические свойства существенно влияет микроструктура, которая образовалась при спекании в воздушной среде при увеличении плотности и размера зерен (при возрастании температуры в воздушной среде) электропроводность образцов увеличивается несмотря на то, что температура термообработки в условиях высокого вакуума была одинакова - $1075{ }^{\circ} \mathrm{C}$. После измерения термоэлектрических свойств образцов установлено, что при увеличении температуры нагрева образцов наблюдается возрастание электропроводности. Наибольшие значения коэффициента Зеебека $(\sim 410 \mu \mathrm{V} / \mathrm{K})$ и термоэлектрического фактора мощности $\left(3,25 \times 10^{-6} \mathrm{~W} / \mathrm{m}^{-1} \mathrm{~K}^{-2}\right)$, определенных при $280^{\circ} \mathrm{C}$, обнаружены у образцов спечённых в воздушной среде при температуре $1175^{\circ} \mathrm{C}$. 